\title{
PENYIRAMAN MEDIA TANAM SAMBUNG PUCUK KOPI (Coffea sp) PADA BERBAGAI KONSENTRASI PGPR
}

\author{
Kafrawi $^{1)}$, Raihan Arif ${ }^{1)}$, Andi Muh Siddiq A Kahrir ${ }^{1)}$, Suriansyah ${ }^{2)}$, Nildayanti'), \\ Zahraeni Kumalawati ${ }^{4}$
}

\author{
1) Program Studi Teknologi Produksi Tanaman Hortikultura \\ 2) Program Studi Budidaya Tanaman Perkebunan \\ 3) Program Studi Pengelolaan Perkebunan Kopi \\ 4) Program Studi Teknologi Produksi Tanaman Pangan \\ Politeknik Pertanian Negeri Pangkajene Kepulauan \\ Jalan Poros Makassar-Pare km 83, Mandalle Kabupaten Pangkep, Sulawesi Selatan \\ Email : Kafrawidjamin@gmail.com
}

\begin{abstract}
ABSTRAK
Tujuan dari percobaan ini untuk menentukan konsentrasi PGPR terbaik untuk mendukung pertumbuhaan sambung pucuk kopi. Percobaan dilakukan dalam bentuk Rancangan Acak Lengkap (RAL) yang terdiri atas 4 perlakuan yaitu tanpa PGPR atau konsentrasi 0 ml.L-1 air, 10 ml.L-1 air, 20 ml.L-1 air, dan 30 ml.L-1 air. Setiap perlakuan terdapat 4 ulangan sehingga terdapat 16 unit percobaan. Hasil percobaan menunjukkan bahwa pemberian PGPR dengan konsentrasi 30 ml.L-1 air terhadap sambung pucuk memberikan hasil yang terbaik pada pertumbuhan tinggi tunas dan diameter tunas. Sedangkan pada konsentrasi $10 \mathrm{ml} . \mathrm{L}-1$ air memberikan pengaruh terbaik pada pertambahan jumlah daun bibit sambung pucuk kopi.
\end{abstract}

Kata kunci : Konsentrasi, PGPR, Bibit sambung pucuk kopi

\begin{abstract}
The aim of this experiment was to determine the best PGPR concentration to support coffee shoot grafting. The experiment was carried out in the form of a completely randomized design (CRD) consisting of 4 treatments, namely without PGPR or control concentration 0 ml.L-1 water), $10 \mathrm{ml} . \mathrm{L}-1$ water, $20 \mathrm{ml} . \mathrm{L}-1$ water, and $30 \mathrm{ml} . \mathrm{L}-1$ water is given to each polybag. Each treatment had 4 replications so that there were 16 experimental units. The results showed that giving PGPR with a concentration of $30 \mathrm{ml} \mathrm{L}-1$ of water to shoot grafts gave the best results on shoot height and shoot diameter growth. Whereas at a concentration of $10 \mathrm{ml} . \mathrm{L}-1$ water gave the best effect on the increase in the number of leaves of coffee shoot grafting seeds.
\end{abstract}

Key words: Concentration, PGPR, Coffee shoot grafting

\section{PENDAHULUAN}

Angka Statistik Perkebunan Indonesia bersumber dari Direktorat Jenderal Perkebunan, menunjukkan bahwa produksi kopi Indonesia tahun 2018 mencapai 722,46 ribu ton. Produksi ini berasal dari 1,24 juta hektar luas areal perkebunan kopi, dimana 95,40\% diusahakan oleh perkebunan milik rakyat $(\mathrm{PR})$ sementara sisanya diusahakan oleh perkebunan besar milik swasta (PBS) sebesar 2,47\% dan perkebunan besar milik negara (PBN) sebesar 2,24\%. 
Indonesia dikenal sebagai produsen dan eksportir kopi di dunia. Berdasarkan data FAO, rata-rata produksi kopi dari tahun 2012-2016 sebesar 683,64 ribu ton per tahun, terbesar keempat setelah Brazil, Vietnam, dan Kolombia. Demikian juga ekspor kopi Indonesia, ratarata dari tahun 2012-2016 sebesar 601,38 ribu ton per tahun, eksportir kopi terbesar keempat di dunia setelah Brazil, Vietnam, dan Kolombia Hasil proyeksi produksi kopi Indonesia hingga tahun 2023 diperkirakan akan mencapai 777,12 ribu ton kopi berasan. Pertumbuhan produksi kopi dari tahun 2019-2023 diperkirakan akan terus naik, dengan kenaikan rata-rata 1,43\% per tahun. Net ekspor (ekspor-impor) kopi Indonesia tahun 2019-2023 diperkirakan juga akan terus naik, dengan kenaikan rata-rata sebesar $0,94 \%$ per tahun. Proyeksi konsumsi/ penggunaan/ ketersediaan untuk konsumsi kopi dalam negeri dari tahun 2019-2023 diperkirakan akan mengalami peningkatan rata-rata sebesar $2,02 \%$ per tahun.

Salah satu strategi peningkatan produksi tanaman kopi yang perlu diperhatikan adalah penggunaan bibit unggul yang biasanya diperoleh dari hasil sambung pucuk kopi. Metode sambung atau grafting memiliki keunggulan dan kelemahan, beberapa keuntungan dalam perbanyakan tanaman secara vegetatif dengan teknik ini diantaranya, lebih cepat berbuah, sifatsifat yang diperoleh tidak berbeda jauh dengan sifat induknya, mempunyai perakaran yang kuat, dapat memperbaiki sifat jenis tanaman, relatif mudah dan sederhana untuk dilakukan (Anonimus, 2015).

Sambung (penyambungan) adalah salah satu teknik perbanyakan vegetatif dengan menyambungkan atau menyisipkan batang atas ke batang bawah. Batang bawah yang digunakan biasanya berasal dari biji, setek bahkan tanaman yang sudah tua untuk diremajakan atau diganti dengan varietas baru. Prinsip melakukan teknik sambung adalah kecocokan atau kompatibel antara batang atas dengan batang bawah. Waktu penyambungan harus tepat, cabang entres atau cabang yang kulitnya bermata tunas tumbuh kekar dan sehat. Waktu penyambungan sebaiknya dilakukan ketika pucuk batang atas dalam keadaan sempurna artinya pucuk belum pecah tetapi daun mudanya sudah mengeras (Sipayung, 2015).

Selain faktor kompatibiltas, hal yang perlu dilakukan dalam keberhasilan penyambungan adalah ketersediaan hara pada media tanam yang diperlukan untuk pertumbuhan bibit sambung agar dapat bertumbuh secara maksimal menghasilkan bibit kopi unggul. Prastowo et al. (2010), menyatakan bahwa seperti jenis tanaman lainnya, tanaman kopi membutuhkan ketersediaan unsur hara mikro maupun makro untuk menundukung pertumbuhan maupun produksinya. Beberapa unsur hara makro yang diperlukan dalam jumlah cukup besar di antaranya adalah $\mathrm{N}, \mathrm{P}, \mathrm{K}, \mathrm{Ca}$, dan $\mathrm{Mg}$, namun penggunaan pupuk kimia secara terus-menerus dapat merusak keseimbangan hara di dalam tanah (Plante, 2007). 
Penggunaan bahan kimia buatan baik pupuk maupun pestisida untuk meningkatan produksi pertanian dapat merusak lingkungan. Pupuk kimia industri terdiri dari nitrogen, fosfor dan kalium. Penggunaan pupuk kimia yang berlebihan menyebabkan polusi udara dan air tanah serta meningkatkan kandungan hara di perairan (eutrofikasi) (Youssef and Eissa, 2014). Dampak negatif lain terhadap ekosistem tanah adalah pengerasan tanah, penurunan bahan organik, kontaminasi logam berat, resistensi hama dan penyakit tertentu, dan dapat menghilangkan jenis predator dan parasitoid (Stoate et al., 2001). Selain itu, tingginya penggunaan pupuk kimia dalam waktu yang lama akan mengakibatkan degradasi lahan baik secara fisik, kimia dan biologi. Solusi untuk memperbaiki unsur hara pada tanah dan tanaman dilakukan pemberian pupuk organik dan pupuk hayati. Pupuk hayati didefinisikan sebagai zat yang mengandung mikroorganisme hidup dan bila diterapkan pada benih, permukaan tanaman, atau tanah, dapat berkolonisasi dengan rhizosfer atau bagian dalam tanaman dan mendorong pertumbuhan tanaman dengan meningkatkan pasokan atau ketersediaan nutrisi utama bagi tanaman inang (Vessey, 2003).

Pupuk hayati adalah produk biologi aktif terdiri dari mikroorganisme yang dapat meningkatkan efisiensi pemupukan, kesuburan dan kesehatan tanah, sedangkan komposisi mikroorganisme/ mikrofauna dan bahan pembawa penyusun pupuk hayati merupakan formula pupuk hayati (PERMENTAN No. 28/Permentan/SR.130/5/2009). Pupuk hayati memberi manfaat bagi pertumbuhan tanaman dan meningkatkan hasil panen (Vessey, 2003). Pupuk hayati berperan menjaga lingkungan tanah melalui fiksasi $\mathrm{N}$ pada tanah yang kaya jenis mikro dan makro-nutrisi, pelarutan $\mathrm{P}$ dan kalium atau mineralisasi, pelepasan zat pengatur tumbuh tanaman, serta produksi antibiotik dan biodegradasi bahan organik (Sinha et al., 2014). Ketika pupuk hayati diaplikasikan pada benih atau tanah, mikroorganisme yang terkandung di dalamnya akan berkembang biak dan berperan aktif dalam pemberian nutrisi dan meningkatkan produktivitas tanaman (Singh et al., 2011).

Terdapat pupuk hayati yang kini mulai meluas penggunaannya yaitu PGPR (Plant Growth Promoting Rhizobacteria). PGPR merupakan kelompok bakteri menguntunkan yang secara aktif mengklonisasi rizoefir. PGPR berperan penting dalam meningkatkan perkembangan perakaran yang berdampak pada pertumbuhan tanaman, hasil panen dan kesuburan lahan (Wahyudi, 2009). Secara umum fungsi PGPR dalam meningkatkan pertumbuhan tanaman dibagi dalam tiga kategori yaitu: (1) sebagai pemacu atau peransang pertumbuhan (biostimulan)dengan mensintesis dan mengatur konsentrasi berbagai zat pengatur tumbuh(fitohormon) seperti IAA, giberelin, sitokinin, dan etilen dalam lingkungan akar; (2) sebagai penyedia hara (biofertilizer) dengan menambah $\mathrm{N} 2$ dari udara secara simbiosis dan 
melarutkan hara $\mathrm{P}$ yang terikat didalam tanah; (3) sebagai pengendali patogen berasal dari tanah (bioprotectans) dengan cara menghasilkan berbagai senyawa atau metabolit anti patogen seperti siderophore $\beta-1,3$ glukanase, kitinase, antibiotik dan sianida ( Yolanda et al.,2011). Berbagai jenis bakteri telah di identifikasi sebagai PGPR sebagian besar berasal dari kelompok gram-negatif dengan juumlah strain paling banyak dari genus psuedomonas dan beberapa dari genus serratia. Selain kedua genus tersebut dilaporkan antara lain genus Pseudomonas sp., Serratia sp., Azotobacter, Azospirillum sp., Acetobacter sp., Burkholderia sp., dan Bacillus spp. (Husen dan Saraswati., 2006).

Plant Growth Promoting Rhizobacteria sangat potensial untuk meningkatkan produktivitas tanaman serta mengurangi penggunaan pupuk anorganik. PGPR mengkolonisasi rhizosfer sekitar perakaran, di permukaan akar, atau dalam jaringan akar (Singh et al., 2011). Mekanisme stimulasi pertumbuhan tanaman oleh PGPR adalah melalui mobilisasi hara, pemacu pertumbuhan melalui produksi fitohormon, dan kemampuan antagonis terhadap penyakit tular tanah (Egamberdieva, 2008), pelarutan dari fosfat anorganik, peningkatan hara besi melalui siderofor pengkhelat besi, dan kandungan volatil yang mempengaruhi signal tanaman (Singh et al., 2011). Banyak spesies bakteri yang mampu memproduksi auksin, ACC deaminase, dan sintesis giberelin dan sitokinin (Van-Loon, 2007). PGPR, dengan antibiosis, kompetisi ruang, dan hara dan induksi resistensi sistemik dalam tanaman, melawan penyebaran patogen akar dan daun (Singh et al., 2011).

Peningkatan produktivitas dan mutu hasil kopi dapat dilakukan dengan cara memperhatikan teknik budidaya tanaman kopi mulai dari penanaman hingga perawatan. Pemupukan dilakukan dengan memperhatikan waktu, dosis dan jenis pupuk serta cara pengaplikasiannya (Prastowo, 2010). Kafrawi et al., (2017), telah memformulasi PGPR mengandung isolat-isolat yang menghasilkan auksin, nitrogen dan phosphor yang di cobakan pada tanaman bawang merah dan memberi pengaruh terhadap jumlah daun dan jumlah umbi. Namun PGPR tersebut belum pernah dicobakan pada bibit sambung tanaman kopi sehingga belum tersedia imformasi tentang konsentrasi PGPR yang tepat untuk aplikasi kedalam media tanam bibit kopi dalam meningkatkan pertumbuhan bibit tanaman kopi, sehingga perlu dilakukan percobaan tentang hal tersebut.

\section{METODE}

Percobaan ini dilakukan pada bulan Agustus sampai bulan Oktober 2019 yang berlokasi di PT TOARCO JAYA, Bokin, Rantebua, Kabupaten Toraja Utara, Sulawesi Selatan. Bibit batang 
bawah kopi dari jenis kopi Robusta dan scion dari jenis kopi Arabika, sedangkan formulasi PGPR mengandung berbagi jenis bakteria Bacillus sp.

Percobaan ini disusun menggunakan Rancangan Acak Kelompok (RAK) dengan perlakuan konsentrasi PGPR (K) dengan 4 taraf perlakuan, yaitu: K0: kontrol (konsentrasi 0 ml.L-1 air), K1: 10 ml.L-1 air, K2 : 20 ml.L-1 air, dan K3 : 30 ml.L-1 air. Setiap perlakuan terdapat 4 ulangan sehingga terdapat 16 unit percobaan. Penyiraman PGPR ke media tanam bibit kopi hasil sambung pucuk dilakukan 2 kali seminggu pada pagi hari sebanyak $\pm 500 \mathrm{~mL}$ per polybag.

\section{HASIL DAN PEMBAHASAN}

\section{Tinggi Tunas Tanaman}

Uji BNT pada Tabel 1 menunjukkan bahwa perlakuan konsentrasi 30 ml.L-1 memperlihatkan tunas tertinggi dari semua perlakuan kosnetrasi PGPR bibit sambungan $(33,19 \mathrm{~cm})$ dan berbeda tidak nyata dengan perlakuan konsentrasi $20 \mathrm{ml} . \mathrm{L}-1(31,45 \mathrm{~cm})$ tetapi berbeda nyata dengan perlakuan konsentrasi $10 \mathrm{ml} . \mathrm{L}-1(15,50 \mathrm{~cm})$ dan control $(10,03 \mathrm{~cm})$. Auksin yang diproduksi oleh PGPR sangat penting dalam pertumbuhan tunas bibit sambung kopi. Konsentrasi PGPR tertinggi yang diberikan pada bibit sambung kopi menyebabkan tersedianya auksin cukup pada media tanam yang diproduksi oleh pupolasi bakteri yang tinggi pula kemudian ditranslokasikan ke tanaman melalui akar. Sejalan dengan Yuliyanto et al., (2015) bahwa konsentrasi auksin yang tepat akan mempercepat deferesiansi sel pada jaringan xylem floem didalam kambium batang atas terhadap batang bawah sehingga mempercepat pertautan.

Tabel 1. Rata-rata Pertambahan Tinggi Tunas Bibit Sambung Pucuk Kopi umur 63 hss (hari setelah sambung)

\begin{tabular}{ccc}
\hline Konsentrasi PGPR & Tinggi Tunas $(\mathbf{c m})$ & NP BNT 0,01 \\
\hline $0 \mathrm{ml} . \mathrm{L}^{-1}$ & $10,03 \mathrm{a}$ & 20,37 \\
$10 \mathrm{ml} . \mathrm{L}^{-1}$ & $15,50 \mathrm{a}$ & \\
$20 \mathrm{ml} . \mathrm{L}^{-1}$ & $31,45 \mathrm{~b}$ & \\
$30 \mathrm{ml} . \mathrm{L}^{-1}$ & $33,19 \mathrm{~b}$ & \\
\hline
\end{tabular}

Keterangan: Nilai rata-rata yang diikuti huruf yang sama $(a, b)$ pada satu kolom berarti berbeda tidak nyata pada taraf 0,01

Menurut Supriyanto dan Saepuloh (2014) pertumbuhan panjang tunas salah satunya dipengaruhi oleh hormon auksin, dengan adanya auksin menyebabkan terjadinya pemanjangan sel. Hal ini searah penelitian Iqbal (2012) bahwa pemberian hormon pada entres sambung pucuk dapat meningkatkan panjang tunas kakao. Sedangkan Campbell et al, (2003), mengatakan auksin merupakan hormon yang berfungsi pada proses pemanjangan sel pada 
tunas muda yang sedang berkembang sehingga tunas akan terus memanjang hingga menjulang tinggi.

\section{Diameter Tunas}

Gambar 2 menunjukkan bahwa perlakuan konsentrasi 30 ml.L-1 memperlihatkan diameter tunas paling besar pada bibit sambung pucuk kopi dengan rata-rata 2,96 cm sedangkan perlakuan yang menunjukkan diameter paling kecil yaitu perlakuan kontrol dengan rata-rata 2,53 cm. Perlakuan konsentrasi PGPR yang tinggi memugkinkan produksi auksin oleh populasi bakteriri yang tinggi pada media tanam yang jumlahnya sesuai kebutuhan dalam memacu pertambahan diameter batang. Djamhuri (2011) hormon auksin pada dosis yang sesuai dapat merangsang pertumbuhan tunas pada tanaman. Campbell et al. (2003) menambahkan bahwa hormon auksin termasuk hormon pertumbuhan yang berfungsi dalam proses mempercepat pertumbuhan, membantu dalam proses pembelahan selsehingga dapat mempercepat pertumbuhan batang.

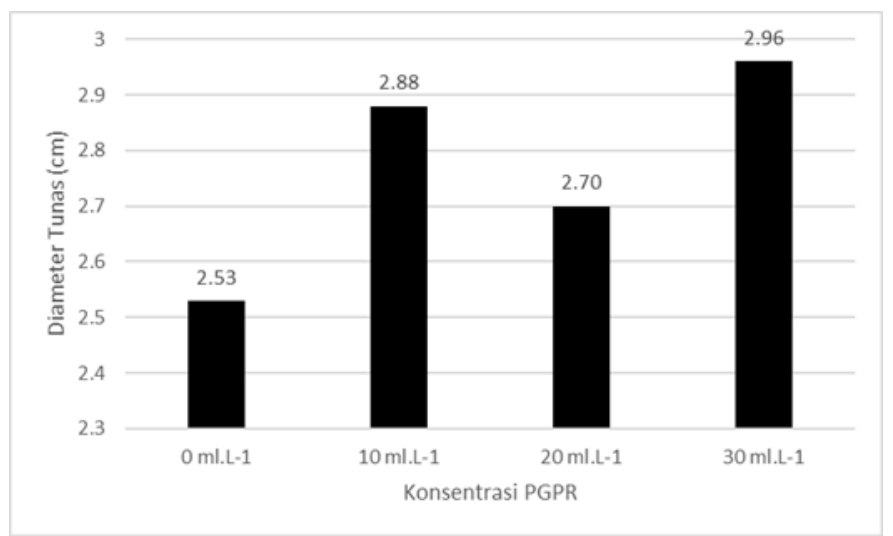

Gambar 2. Rata-rata pertambahan diameter tunas pada bibit sambung pucuk kopi umur 63 hss

Pertumbuhan lebih lanjut seperti pertumbuhan diameter tunas dan atau batang, aktifitas mikroba pada PGPR konsentrasi 30 ml.L-1 didalam media tanam bibit sambung kopi dapat efektif melakukan fiksasi nitrogen dan pada gilirannya dimanfaatkan oleh bibit sambung kopi untuk pertumbuhannya. Populasi bakteri PGPR terbanyak pada aplikasi konsentrasi $30 \mathrm{ml} . \mathrm{L}-1$ sangat berperan dalam berjalannya mekanisme fiksasi nitrogen secara maksimal dibandingkan perlakuan konsentrasi PGPR lebih rendah sehingga lebih mendukung pertumbuhan tinggi tunas dan diameter batang. Semakin tinggi populasi mikroba tanah semakin tinggi aktivitas biokimia dalam tanah dan semakin tinggi indeks kualitas tanah (Saraswati dan Sumarno, 2016). Menurut Yolanda et al (2011), PGPR berfungsi sebagai pemacu atau perangsang pertumbuhan (biostimulan) dengan mensintesis dan mengatur konsentrasi berbagai zat pengatur tumbuh 
(fitohormon) seperti IAA, giberelin, sitokinin, dan etilen dalam lingkungan akar dan sebagai penyedia hara (biofertilizer) dengan menambat N2 dari udara secara simbiosis dan melarutkan hara $\mathrm{P}$ yang terikat didalam tanah.

Unsur nitrogen termasuk unsur utama dan merupakan faktor pembatas dalam pertumbuhan, sehingga merupakan kunci keberhasilan pertumbuhan tanaman (Purwaningsih, 2004). Nitrogen memiliki fungsi untuk memperbaiki pertumbuhan vegetatif tanaman seperti, pertumbuhan tinggi tanaman, diameter batang, pertumbuhan daun, dan akar tanaman. Bakteri mampu melakukan penambatan nitrogen udara maupun simbiosis (Hindersah dan Simarmata, 2004). Karbon diperlukan oleh mikroorganisme sebagai sumber energi dan nitrogen diperlukan untuk membentuk protein (Sutanto, 2002).

\section{Jumlah daun}

Gambar 1 menunjukkan bahwa perlakuan konsentrasi 10 ml.L-1 air memperlihatkan jumlah helai daun paling banyak pada bibit sambung pucuk kopi dengan rata-rata 6,5 helai sedangkan paling sedikit yaitu perlakuan kontrol (konsentrasi 0 ml.L-1 air) dengan rata-rata 3,5 helai. Khoiriyah et al. (2013) menyatakan jenis dan konsentrasi zat pengatur tumbuh memberikan pengaruh yang berbeda terhadap tanaman tertentu. Hormon auksin dapat memacu kinerja hormon gibberelin dalam pemanjangan ruas-ruas yang menyebabkan meningkatnya jumlah nodus dan akan menambah jumlah daun (Salisburry dan Ross, 1995). Sedangkan Yuliyanto et al. (2015) auksin dalam bentuk senyawa IBA pada grafting dapat meningkatkan jumlah daun.

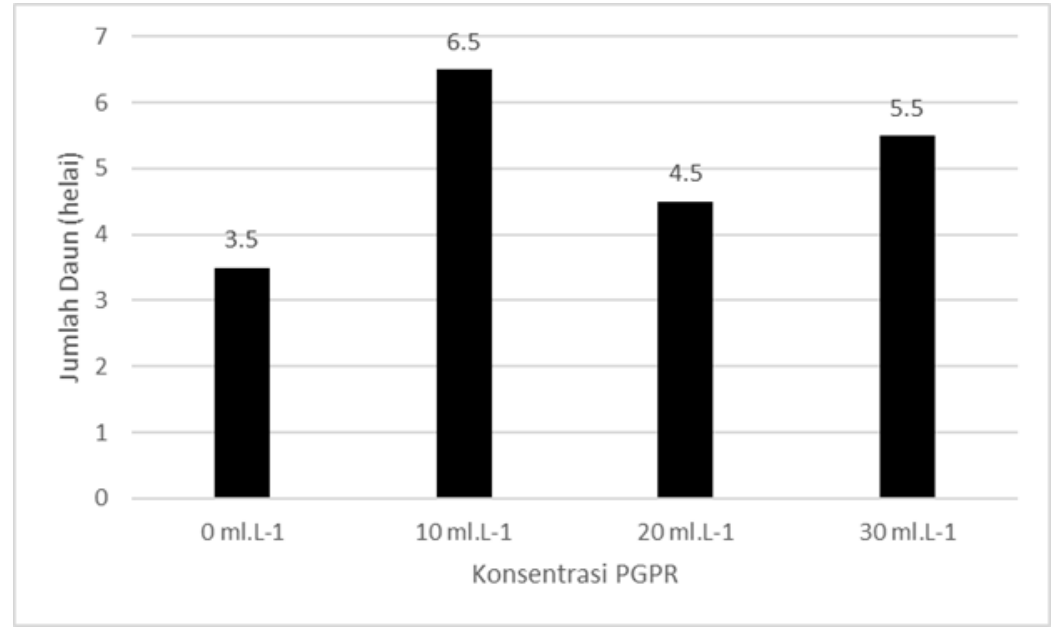

Gambar 1. Rata-rata jumlah daun sambung pucuk kopi umur 63 hss (hari setelah sambung) (hari setelah sambung) 
Berbeda dengan parameter tinggi tunas dan diameter batang, jumlah daun terbanyak pada percobaan ini justru diperoleh dari perlakuan konsentrasi PGPR 10 ml.L-1. Diduga hal ini terjadi lebih dipengaruhi oleh rendahhnya nutrisi nitrogen yang diproduksi oleh PGPR karena pada populasi bakteri yang rendah menyebabkan fiksasi nitrogen juga rendah sehingga hara nitrogen yang terbatas lebih diarahkan untuk mendukung pertumbuhan jumlah daun pada buku sementara ruas berkembang lebih pendek. Padahal menurut Wiroatmodjo dan Najib (1995), peningkatan dosis pupuk nitrogen dapat meningkatkan jumlah daun.

\section{KESIMPULAN}

Pemberian PGPR terhadap sambung pucuk kopi konsentrasi 30 ml.L-1 air memberikan pengaruh terbaik terhadap pertambahan tinggi tunas dan diameter tunas dari bibit sambung pucuk kopi. Sedangkan pada konsentrasi 10 ml.L-1 air memberikan hasil yang terbaik dalam pertambahan jumlah daun bibit sambung pucuk kopi.

\section{UCAPAN TERIMA KASIH}

Disampaikan terima kasih dan penghargaan kepada Direktorat Jenderal Pendidikan Vokasi, Kementerian Pendidikan dan Kebudayaan (Kemendikbud) yang telah mendanai penelitian ini.

\section{DAFTAR PUSTAKA}

Anonimus, 2015. http://id.m.wikipedia.org/wiki/teknik_menyambung_tanaman. diakses tanggal 15 juni 2015.

Campbell, Neil. A, Jane B. Reece.2003. Biologi Jilid 2 Edisi Ke Lima. Jakarta : PT Gelora Aksara Pratama . Erlangga.

Djamhuri, E. 2011. Pemanfaatan air kelapa untuk meningkatkan pertumbuhan setek pucuk meranti tembaga (Shorea leprosula Miq.). Jurnal Silvikultur Tropika. 2 (1): 5-8

Egamberdieva, D. 2008. Plant growth promoting properties of rhizobacteria isolated from wheat and pea grown in loamy sand soil. Turk J. Biol. 32: 9-15. Pemanfaatan Mikroba Indigenous Pada Tanaman Kopi Balai Penelitian Tanaman Industri dan Penyegar Jalan Raya Pakuwon km 2 Parungkuda, Sukabumi 43357 maman.herman@gmail.com

Hindersah, R. dan T. Simarmata. 2004. Potensi rhizobacteri Azotobacter dalam meningkatkan kesehatan tanah. Jurnal Natura Indonesia. 5:127-133.

Husen E, Saraswati R. 2003. Effect of IAA-producing bacteria on the growth of hot pepper. J Mikrobiol Indones 8: 22-26. 
Iqbal, M. 2012. Pengaruh Perendaman Entris Dalam Ektrak Jagung Dan Kangkung Terhadap Pertumbuhan Sambung Pucuk Kakao (Theobroma cacao. L). Jurnal Agronomi. Universitas Hasanuddin Makassar.

Kafrawi, Nildayanti, Zahraeni K, Baharuddin, 2017. Comparison of IAA Production by Shallot Rhizosphere Isolated Bacteria in Solid and Liquid Media and Their Effect on Shallot Plant Growth. J Microb Biochem Technol 9: 266-269. doi:10.4172/19485948.1000375

Khoiriyah N., E. S. Rahayu, dan L. Herlina. 2013. Induksi perbanyakan tunas Rosadamascenamill. Dengan penambahan auksin dansitokinin.Unnes Journal of Life Science. 2 (1): 57-63

Plante, A. F. 2007. Soil Biogeochemical Cycling of Inorganic Nutrients And Metals. Soil Microbiology, Ecology, and Biochemistry. Third edition. Elsevier Inc. USA. Pemanfaatan Pupuk Hayati (BIOFERTILIZER) Pada Tanaman Rempah dan Obat Biofertilizer Utilization on Spices and Medicinal Plants Perspektif Vol. 16 No. 1 /Juni 2017. Hlm $33-43$

Prastowo, B., Karmawati, E., Rubiyo, Siswanto, Indrawanti, C., \& Munarso, J. (2010). Budidaya dan pasca panen kopi. Bogor: Pusat Penelitian dan pengembanagan Perkebunan. Pengaruh Pupuk Kandang Dengan Penambahan Mikroba Pelarut Fosfat Terhadap Pertumbuhan dan Hasil Kopi Robusta Volume 5, Nomor 2, Juli 2018.

Purwaningsih, S. 2004. Isolasi, Enumerasi, Dan Karakterisasi Bakteri Rhizobium Dari Tanah Kebun Biologi Wamena, Papua. Jurnal dipublikasikan. Bidang Mikrobiologi, Pusat Penelitian Biologi, Lembaga Ilmu Pengetahuan Indonesia (Lipi), Bogor.

Salisbury, F.B., dan C.W. Ross. 1995. Fisiologi tumbuhan. Jilid 1 Terjemahan Diah R. Lukman dan Sumaryo. ITB, Bandung

Saraswati dan Sumarno, 2016. Pemanfaatan Mikroba Penyubur Tanah sebagai Komponen Teknologi Pertanian. eJournal.Litbang.Pertanian.go.id

Singh, J.S, V.C. Pandey, D.P. Singh. 2011. Efficient soil microorganisms: a new dimension for sustainable agriculture andenvironmental development. Agric Ecosyst Environ 140:339-353. Pemanfaatan Pupuk Hayati (Biofertilizer) Pada Tanaman Rempah Dan Obat Biofertilizer Utilization on Spices and Medicinal Plants Perspektif Vol. 16 No. 1 /Juni 2017. Hlm 33 -43

Sinha, R.K., D. Valani, K. Chauhan, S. Agarwal. 2014. Embarking on a second green revolution for sustainable agriculture by vermiculture biotechnology using earthworms: reviving the dreams of Sir Charles Darwin. Int J Agric Health Saf. 1:5064. Pemanfaatan Pupuk Hayati (Biofertilizer) Pada Tanaman Rempah Dan Obat Biofertilizer Utilization on Spices and Medicinal Plants Perspektif Vol. 16 No. 1 /Juni 2017. Hlm $33-43$

Sipayung, P. 2015. Penuntun Praktikum Pembiakan Vegetatif. Fakultas Pertanian Universitas Katolik Santo Thomas Sumatera Utara. Medan. 
Stoate C, N.D Boatman, R.J Borralho, C.R Carvalho, G.R de Snoo, and P. Eden. 2001. Ecological impacts of arable intensification in Europe. J Environ Manage,63 (4) : 337 65. Pemanfaatan Pupuk Hayati (Biofertilizer) Pada Tanaman Rempah Dan Obat Biofertilizer Utilization on Spices and Medicinal Plants Perspektif Vol. 16 No. 1 /Juni 2017. Hlm $33-43$

Supriyanto dan A. Saepulloh. 2014. Pengaruh bahan stek dan hormon IBA (Indole Butiric Acid) terhadap pertumbuhan stek jabon merah (Anthocephalus macrophyllus). Jurnal Silvikultur Tropika (5) : 104-112.

Sutanto, R. 2002. Pertanian Organik : Menuju Pertanian Alternatif dan Berkelanjutan. Penerbit Kanisius. Yogyakarta. Wiraatmadja, Wayan, 2017. Defisiensi dan toksisitas Hara Mineral Serta Responnya Terhadap hasil. Bahan Ajar program studi agroekoteknologi, Fakultas pertanian, Unud

Van-Loon, L. C. 2007. Plant responses to plant growth-promoting rhizobacteria. Eur J Plant Pathol. 119: 243-254. Pemanfaatan Mikroba Indigenous Pada Tanaman Kopi Balai Penelitian Tanaman Industri dan Penyegar Jalan Raya Pakuwon km 2 Parungkuda, Sukabumi 43357 maman.herman@gmail.com

Vessey, J. K. 2003. Plant growth promoting rhizobacteria as biofertilizers. Plant Soil 255 : 571 586 Pemanfaatan Pupuk Hayati (Biofertilizer) Pada Tanaman Rempah Dan Obat Biofertilizer Utilization on Spices and Medicinal Plants Perspektif Vol. 16 No. 1 /Juni 2017. Hlm $33-43$

Wahyudi, A.T.2009. Rhizobacteria Pemacu Pertumbuhan Tanaman : Prospeknyasebagai Agen Biostimulator \& Biokontrol. Nano Indonesia Tangerang

Wiroadmodjo, J dan Najib, M. 1995 Pengaruh Dosis Nitrogen dan Kalium terhadap Produksi dan Mutu Tembakau Temanggung pada Tumpang Sisip Kubis-Tembakau di Pujon Malang. Buletin Agronomi Vol. 23 No. 2, 1995: 17-25

Yolanda, E,M,G.,D.J. Hernandez, C,A. Hernandez, M,A,M. Esparza, M,B. Cristales,L,F.Ramirez, R.D.M. Conterasdan J.M.Rojas 2011. Growth Response Of Maize PlantletsInoculated With Enterobacter spp., as a Model For Alternative Agriculture. Microbiologia 4(3):287-293.

Youssef, M.M.A., and M.F.M Eissa. 2014. Biofertilizers and their role in management of plant parasitic nematodes. A review. E3 J Biotechnol. Pharm Res. 13:1-6. Pemanfaatan Pupuk Hayati (Biofertilizer) Pada Tanaman Rempah Dan Obat Biofertilizer Utilization on Spices and Medicinal Plants Perspektif Vol. 16 No. 1 /Juni 2017. Hlm $33-43$

Yuliyanto, G. A., E Setiawan, dan K Badami. 2015. Efek pemberian IBA terhadap pertautan sambung samping tanaman srikaya. Agrivor. 8 (2): 51-57. 